\title{
Factors affecting knowledge regarding unmet need on fertile aged women in Indonesia: evaluation of 2012 and 2017 IDHS
}

\author{
Achmad Kemal Harzif ${ }^{1 *}$ D, Mila Maidarti ${ }^{1}$, Fransisca Novi Handayaning ${ }^{1}$ and Azizah Fitriayu Andyra ${ }^{2}$
}

\begin{abstract}
Background: The Family Planning (FP) Program is a national method of controlling population growth rates while improving maternal and child health. Indonesia, as one of the largest countries, has abysmally low contraceptive coverage. One of its main issues is unmet contraceptive needs. This study aims to determine the factors that influence women's unmet need of childbearing age (WCA) in Indonesia.

Methods: We performed an unpaired comparative analytic study with a cross-sectional method was conducted on secondary data obtained from 2012 to 2017 Indonesia Demographic and Health Survey (IDHS). The subjects in this study were all women of childbearing age (15-49 years). Subjects with incomplete data were excluded from the study. Unmet need was defined as WCA who did not use contraception but decline to have more children or wanted to delay their pregnancies. Chi-square analysis was performed on categorical data and Mann-Whitney $U$ analysis on numerical data.

Result: A total of 45,607 WCA in the 2012 IDHS data and 29,627 WCA in the 2017 IDHS data were included in the study. In the 2012 IDHS data, factors influencing unmet needs were age $(p=0.023)$ and parity $(p<0.0001)$. In the 2017 IDHS data, factors influencing unmet needs were the residential area $(p=0.003)$, level of education $(p=0.008)$, level of spouse's education ( $p<0.0001)$, employment status $(p=0.03)$, possession of electricity $(p=0.001)$, and possession of television $(p=0.01)$.
\end{abstract}

Conclusion: Factors affecting unmet needs are age, parity, residential area, level of education, level of spouse's education, employment status, possession of television, and possession of electricity. There were no recurring factors on 2012 and 2017 IDHS data.

Keywords: Family planning, Contraception, Unmet need

\section{Plain language summary}

The Family Planning (FP) Program is a national method of controlling population growth rates while improving maternal and child health. Indonesia, as one of the largest countries, has abysmally low contraceptive coverage. One of its main issues is unmet contraceptive needs. This study aims to determine the factors that influence women's unmet need of childbearing age (WCA) in Indonesia.

\footnotetext{
*Correspondence: kemal.achmad@gmail.com

1 Department of Obstetrics and Gynecology, Cipto Mangunkusumo

National Referral Hospital, Faculty of Medicine, University of Indonesia, Jakarta, Indonesia

Full list of author information is available at the end of the article
} permits use, sharing, adaptation, distribution and reproduction in any medium or format, as long as you give appropriate credit to the original author(s) and the source, provide a link to the Creative Commons licence, and indicate if changes were made. The images or other third party material in this article are included in the article's Creative Commons licence, unless indicated otherwise in a credit line to the material. If material is not included in the article's Creative Commons licence and your intended use is not permitted by statutory regulation or exceeds the permitted use, you will need to obtain permission directly from the copyright holder. To view a copy of this licence, visit http://creativecommons.org/licenses/by/4.0/. The Creative Commons Public Domain Dedication waiver (http://creativeco mmons.org/publicdomain/zero/1.0/) applies to the data made available in this article, unless otherwise stated in a credit line to the data. 
An unpaired comparative analytic study with a cross-sectional method was conducted on secondary data obtained from 2012 and 2017 Indonesia Demographic and Health Survey (IDHS). The subjects in this study were all women of childbearing age (15-49 years). Subjects with incomplete data were excluded from the study. Unmet need was defined as WCA who did not use contraception but decline to have more children or wanted to delay their pregnancies. Chi-square analysis was performed on categorical data and Mann-Whitney $U$ analysis on numerical data. A total of 45,607 WCA in the 2012 IDHS data and 29,627 WCA in the 2017 IDHS data were included in the study. In the 2012 IDHS data, factors influencing unmet needs were age and parity. In the 2017 IDHS data, factors influencing unmet needs were the residential area, level of education, level of spouse's education, employment status, possession of electricity, and possession of television.

In conclusion, factors affecting unmet needs are age, parity, residential area, level of education, level of spouse's education, employment status, possession of television, and possession of electricity. There were no recurring factors on 2012 and 2017 IDHS data.

\section{Background}

It is estimated that the global population would reach 7 billion people, And with increasing life expectancy every year, it is predicted to continue to grow and reach 8 billion in 2023 [1, 2].

Over the past 20 years, the usage of contraceptives in developing countries has decreased the number of maternal mortality simply by reducing unplanned pregnancies [3]. This action directly decreases the number of illegal abortions and high-risk pregnancies. Nevertheless, these successes are far from perfect. Previous research states that as many as $30 \%$ of maternal deaths can be further reduced by meeting unmet needs for contraception [3]. In addition, contraception may also increase perinatal outcomes by increasing the interval between pregnancies [3, 4].

Methods and forms of pregnancy planning differ widely, starting from traditional techniques, such as periodic abstinence, disrupted intercourse, and methods from myths and beliefs to modern techniques that have been studied for their efficacy. The intrauterine device (IUD), condoms, hormonal (pills), implants, and birth control injections are some well-known pregnancy planning approaches in the culture. There are also modern procedures, such as vasectomy and tubectomy, which are not commonly known or even feared by the public [5].

Based on data in 2017, traditional contraceptive methods were used by $4.6 \%$ of women of childbearing age (WCA) in Indonesia, while modern methods were used by $41.4 \%$ of WCA. The most widely used modern methods are injection (20.9\%), pill (8.7\%), IUD (3.5\%), and implant $(3.4 \%)$. Other methods, such as the lactational amenorrhea method (LAM) and male sterilization, were only used by $0.1 \%$ of all WCA $[6,7]$.

Unmet need is one of the persistent problems found in every country related to the provision of contraceptive services. Unmet need is defined as WCA who decline to have more children or delay pregnancies but do not use contraception $[6,8]$.

The level of unmet need varies from country to country, with a higher percentage in developing countries such as Uganda, Haiti, and Ghana [9]. Based on 2014 data, it was found that the amount of unmet need in Indonesia ranged from 10 to $11 \%$, more or less the same as other Asian countries [9].

Previous studies have shown that several interventions may be utilized to increase contraceptive use rates. However, unmet need is one of the most prevalent problems to be addressed. Currently, there were only a few studies regarding unmet contraceptive needs in Indonesia. This study aims to determine the factors influencing unmet needs in Indonesia.

\section{Methods}

An analytic observational study with a cross-sectional method was done using re-analysis of 2012 and 2017 Indonesia Demographic and Health Survey (IDHS) raw data. The study population was WCA, whose data was recorded on IDHS. Patients with incomplete records were excluded from this study. 45,607 subjects were recorded on 2012 IDHS, while 29,267 subjects were recorded on 2017 IDHS.

Risk factors analyzed in this study were age, parity, history of sexually transmitted disease, residential area, level of education, level of spouse's education, employment status, socioeconomic status, possession of electricity, radio, television and cellphone, smoking status, and the willingness of discussing puberty with daughter. Unmet need is defined as WCA who did not use any form of modern contraception but decided to delay or prevent birth.

Baseline characteristics were then analyzed and compared. Bivariate analysis between subjects' characteristics and contraceptive knowledge was done. Multivariable analysis was done to determine factors associated with 
contraceptive knowledge and unmet need. Ethical clearance was issued from the health research and ethical committee in Faculty of Medicine, University of Indonesia.

\section{Results}

Using the raw data of Indonesian Demographic and Health Survey (IDHS), 45,607 respondents from 2012 IDHS data and 29,267 respondents from 2017 IDHS data were analyzed. Table 1 (2012 IDHS) and Table 2 (2017 IDHS) investigated the relationship between characteristics of subjects and unmet needs.

Subsequently, a multivariable analysis was done between characteristics and unmet needs. The result could be seen in Table 3 (2012 IDHS) and Table 4 (2017 IDHS).

\section{Discussion}

In this study, it is clear that numerous factors were affecting unmet needs in WCA. The family planning program is a program that has succeeded in increasing contraceptive use by as much as $60 \%$ in couples worldwide [10]. It is estimated that there are 225 million women in the world whose contraceptive needs are still not being met each year. The situation is unfortunate, considering that contraception in an unmet need population can further prevent 36 million abortions, 70,000 maternal deaths, and 52 million unwanted pregnancies [10].

Age is one of the factors that determine the use of contraception. Previous research focusing on women aged 15-24 has shown that contraceptive knowledge and use among younger women tend to be lower, especially when combined with lower education and rural areas [11, 12]. Previous studies have also shown that this is related to more significant concern on younger women and would translate into lower contraceptive coverage in the younger age category [13].

Education, spouse's education, and possession of various facilities (electricity, radio, television, cellphone, and internet) are linked to the availability of information flows that reach the WCA. Previous research in Bangladesh and Ghana has shown that education is a very influential factor in the use of contraception because women with higher levels of education tend to have a better understanding of the benefits and risks of using contraception [14, 15]. Better education would also lead to higher levels of contraceptive use [14, 16, 17].

Afterward, it was also known that factors associated with unmet needs are age, parity, residential area, level of education, level of spouse's education, employment status, possession of television, and possession of electricity. The number of unmet needs is directly related to the number of unplanned and unwanted pregnancies.
Table 1 Relationship between characteristics and Unmet need in 2012 IDHS

\begin{tabular}{|c|c|c|c|c|}
\hline \multirow[t]{2}{*}{ Characteristics } & \multicolumn{2}{|l|}{ Unmet need } & \multirow[t]{2}{*}{$p$} & \multirow[t]{2}{*}{ OR (Cl 95\%) } \\
\hline & Yes & No & & \\
\hline Age & $35(15-49)$ & $31(15-49)$ & $<0.001$ & \\
\hline Parity & $2(0-13)$ & $1(0-14)$ & 0.001 & \\
\hline \multicolumn{5}{|c|}{ Sexually transmitted disease history } \\
\hline Yes & $1(2.6 \%)$ & $37(97.4 \%)$ & 0.270 & $0.42(0.06-3.09)$ \\
\hline No & $2.717(6.0 \%)$ & 42.559 (94.0\%) & & \\
\hline \multicolumn{5}{|l|}{ Residential area } \\
\hline City & $1.402(5.9 \%)$ & 22.404 (94.1\%) & 0.322 & $0.96(0.89-1.04)$ \\
\hline Rural & $1.332(6.1 \%)$ & $20.469(93.9 \%)$ & & \\
\hline \multicolumn{5}{|l|}{ Education } \\
\hline Uneducated & $110(7.3 \%)$ & $1.390(92.7 \%)$ & $<0.001$ & \\
\hline Primary & $1100(7.3 \%)$ & $14.025(92.7 \%)$ & & \\
\hline Junior high & $1194(5.1 \%)$ & $22.236(94.9 \%)$ & & \\
\hline Senior high & $331(6.0 \%)$ & $5.222(94.0 \%)$ & & \\
\hline Education (years) & $6(0-6)$ & $5(0-6)$ & $<0.001$ & \\
\hline \multicolumn{5}{|l|}{ Spouse's education } \\
\hline Uneducated & 69 (7.1\%) & 909 (92.9\%) & $<0.001$ & \\
\hline Primary & $1.010(7.4 \%)$ & $12.664(92.6 \%)$ & & \\
\hline Junior high & $1.287(7.4 \%)$ & $16.045(92.6 \%)$ & & \\
\hline Senior high & $342(9.7 \%)$ & $3.191(90.3 \%)$ & & \\
\hline \multicolumn{5}{|l|}{ Employment status } \\
\hline Working & $1.558(6.2 \%)$ & $23.701(93.8 \%)$ & 0.084 & $1.07(0.99-1.16)$ \\
\hline Not working & $1.176(5.8 \%)$ & $19.164(94.2 \%)$ & & \\
\hline \multicolumn{5}{|c|}{ Socioeconomic status } \\
\hline First quintile & $621(8.0 \%)$ & $7.146(92.0 \%)$ & $<0.001$ & \\
\hline Second quintile & $513(5.8 \%)$ & $8.272(94.2 \%)$ & & \\
\hline Third quintile & $483(5.2 \%)$ & $8.760(94.8 \%)$ & & \\
\hline Fourth quintile & $535(5.5 \%)$ & $9.208(94.5 \%)$ & & \\
\hline Fifth quintile & $583(5.8 \%)$ & $9.488(94.2 \%)$ & & \\
\hline \multicolumn{5}{|c|}{ Possession of electricity } \\
\hline Yes & $2.527(5.8 \%)$ & $40.796(94.2 \%)$ & $<0.001$ & $0.51(0.43-0.61)$ \\
\hline No & $152(10.8 \%)$ & $1.260(89.2 \%)$ & & \\
\hline \multicolumn{5}{|l|}{ Possession of radio } \\
\hline Yes & $823(5.2 \%)$ & $15.091(94.8 \%)$ & $<0.001$ & $0.79(0.73-0.86)$ \\
\hline No & $1.852(6.4 \%)$ & $26.937(93.6 \%)$ & & \\
\hline \multicolumn{5}{|c|}{ Possession of television } \\
\hline Yes & $2.275(5.8 \%)$ & $37.289(94.2 \%)$ & $<0.001$ & $0.72(0.64-0.80)$ \\
\hline No & $406(7.8 \%)$ & $4.776(92.2 \%)$ & & \\
\hline \multicolumn{5}{|l|}{ Smoking } \\
\hline Yes & 102 (9.5\%) & 969 (90.5\%) & $<0.001$ & $0.16(0.14-0.20)$ \\
\hline No & $2.629(5.9 \%)$ & $41.897(94.1 \%)$ & & \\
\hline \multicolumn{5}{|l|}{ Puberty discussion } \\
\hline Yes & $348(8.3 \%)$ & 3.859 (91.7\%) & 0.559 & $1.05(0.90-1.22)$ \\
\hline No & $370(7.9 \%)$ & $4.294(92.1 \%)$ & & \\
\hline
\end{tabular}

Previous research has shown a 16-fold chance of developing an unwanted pregnancy in women with unmet needs [17].

Age, parity, education, spouse's education, and access to information would influence the incidence of unmet 
Table 2 Relationship between characteristics and Unmet need in 2017 IDHS

\begin{tabular}{|c|c|c|c|c|}
\hline \multirow[t]{2}{*}{ Characteristics } & \multicolumn{2}{|l|}{ Unmet need } & \multirow[t]{2}{*}{$p$} & \multirow[t]{2}{*}{ OR (Cl 95\%) } \\
\hline & Yes & No & & \\
\hline Age & $36(15-49)$ & $32(15-49)$ & $<0.001$ & \\
\hline Parity & $2(0-13)$ & $1(0-13)$ & 0.001 & \\
\hline \multicolumn{5}{|c|}{ Sexually transmitted disease history } \\
\hline Yes & $6(6.5 \%)$ & $86(93.5 \%)$ & 0.097 & $1.17(0.51-2.69)$ \\
\hline No & $2.771(5.6 \%)$ & $46.590(94.4 \%)$ & & \\
\hline \multicolumn{5}{|l|}{ Residential area } \\
\hline City & $1.434(5.6 \%)$ & $24.109(94.4 \%)$ & 0.858 & $0.99(0.92-1.07)$ \\
\hline Rural & $1.361(5.7 \%)$ & $22.723(94.3 \%)$ & & \\
\hline \multicolumn{5}{|l|}{ Education } \\
\hline Uneducated & $53(6.4 \%)$ & $770(93.6 \%)$ & $<0.001$ & \\
\hline Primary & $888(6.5 \%)$ & $12.675(93.5 \%)$ & & \\
\hline Junior high & $1.501(5.5 \%)$ & $25.998(94.0 \%)$ & & \\
\hline Senior high & $351(4.5 \%)$ & $7.390(95.5 \%)$ & & \\
\hline Education (years) & $6(0-6)$ & $5(0-12)$ & $<0.001$ & \\
\hline \multicolumn{5}{|l|}{ Spouse's education } \\
\hline Uneducated & $59(10.5 \%)$ & $504(89.5 \%)$ & $<0.001$ & \\
\hline Primary & $850(7.1 \%)$ & $11.083(92.9 \%)$ & & \\
\hline Junior high & $1.511(8.0 \%)$ & $17.296(92.0 \%)$ & & \\
\hline Senior high & $330(7.7 \%)$ & $3.934(92.3 \%)$ & & \\
\hline \multicolumn{5}{|l|}{ Employment status } \\
\hline Working & $1.492(5.6 \%)$ & $24.955(94.4 \%)$ & 0.932 & $1.00(0.93-1.08)$ \\
\hline Not working & $1.302(5.6 \%)$ & $21.850(94.4 \%)$ & & \\
\hline \multicolumn{5}{|c|}{ Socioeconomic status } \\
\hline First quintile & $523(6.2 \%)$ & $7.941(93.8 \%)$ & 0.097 & \\
\hline Second quintile & $549(5.8 \%)$ & $8958(94.2 \%)$ & & \\
\hline Third quintile & $550(5.5 \%)$ & $9.539(94.5 \%)$ & & \\
\hline Fourth quintile & $563(5.3 \%)$ & $10.020(94.7 \%)$ & & \\
\hline Fifth quintile & $609(5.5 \%)$ & $10.375(94.5 \%)$ & & \\
\hline \multicolumn{5}{|c|}{ Possession of electricity } \\
\hline Yes & $2.621(5.6 \%)$ & $44.488(94.4 \%)$ & 0.013 & $0.75(0.60-0.94)$ \\
\hline No & $85(7.3 \%)$ & $1.084(92.7 \%)$ & & \\
\hline \multicolumn{5}{|l|}{ Possession of radio } \\
\hline Yes & $563(5.0 \%)$ & 10.665 (95.0\%) & 0.002 & $0.86(0.78-0.95)$ \\
\hline No & $2.142(5.8 \%)$ & 34.885 (94.2\%) & & \\
\hline \multicolumn{5}{|c|}{ Possession of television } \\
\hline Yes & $2.461(5.5 \%)$ & $42.089(94.5 \%)$ & 0.010 & $0.83(0.73-0.96)$ \\
\hline No & $244(6.5 \%)$ & $3.483(93.5 \%)$ & & \\
\hline \multicolumn{5}{|l|}{ Access to internet } \\
\hline Yes & $1.095(4.6 \%)$ & $22.813(95.4 \%)$ & $<0.001$ & $0.68(0.62-0.73)$ \\
\hline No & $1.657(6.6 \%)$ & $23.337(93.4 \%)$ & & \\
\hline \multicolumn{5}{|c|}{ Possession of cellphone } \\
\hline Yes & $2.121(5.5 \%)$ & 36.769 (94.5\%) & 0.002 & $0.86(0.79-0.95)$ \\
\hline No & $665(6.2 \%)$ & $10.014(93.8 \%)$ & & \\
\hline
\end{tabular}

needs in Indonesia. Previous research conducted in Indonesia in 2015 also showed similar results that age and parity would determine the incidence of unmet need in WCA [18]. Therefore, further education is
Table 3 Multivariable analysis of Unmet need 2012 IDHS

\begin{tabular}{lccc}
\hline Characteristics & \multicolumn{1}{c}{$\boldsymbol{p}$} & OR & Cl 95\% \\
\hline Age $<20$ years & 0.023 & 1.30 & $1.04-1.62$ \\
Parity: nulliparity & $<0.0001$ & 8.96 & $7.17-11.20$ \\
\hline
\end{tabular}

Table 4 Multivariable analysis of Unmet need 2017 IDHS

\begin{tabular}{lccc}
\hline Characteristics & \multicolumn{1}{c}{$\boldsymbol{p}$} & \multicolumn{1}{c}{ OR } & \multicolumn{1}{c}{ Cl 95\% } \\
\hline Residential area: city & 0.003 & 0.89 & $0.82-0.96$ \\
Education: uneducated & 0.008 & 0.68 & $0.51-0.90$ \\
Spouse's education: uneducated & $<0.0001$ & 14.58 & $11.76-18.09$ \\
Employment status: working & 0.030 & 0.92 & $0.85-0.99$ \\
Possession of electricity: no & 0.001 & 1.30 & $1.12-1.52$ \\
Possession of television: no & 0.010 & 0.82 & $0.71-0.95$ \\
\hline
\end{tabular}

needed, not only about family planning and contraceptive programs but also the ideal number of children for couples [19].

One of the considerations affecting the decision on contraceptive use is the characteristics of the spouse. As one of the countries with strong patriarchal values, WCA in Indonesia has difficulties ranging from accessing school and sexual education to not having the right to determine the number of children deemed appropriate [10]. In this report, women with lower spouse's education are more likely to be identified as an unmet need. Previous research has shown that women in developing countries appear to be rejected by their spouses, who desire more offspring. They also have many obstacles and must struggle harder in order to have access to contraception [10, 20].

In conclusion, factors affecting unmet needs range from intrinsic characteristics such as age and parity to spouse's characteristics such as education and socioeconomic status. There were no recurring risk factors. However, the risk factors multiplied in the later years. Comprehensive education and contraceptive provision would be beneficial to improve the rate of contraceptive use in Indonesia.

\section{Conclusions}

Factors affecting unmet needs are age, parity, residential area, level of education, level of spouse's education, employment status, possession of television, and possession of electricity. No recurring factors were affecting unmet need on 2012 and 2017 IDHS data. 


\section{Abbreviations}

FB: Family Planning; WCA: Women of childbearing age; IDHS: Indonesia demographic and health survey; IUD: Intrauterine device; LAM: Lactational amenorrhea method.

\section{Acknowledgements}

Not applicable.

\section{Authors' contributions}

AKH conceptualized the idea and gathered the data; MM extracted and interpreted the results; FNH wrote the initial manuscript and managed the resources; AFA analyzed and contributed to writing the manuscript. All of the authors read and approved the final manuscript.

\section{Funding}

The authors fully financed the funding for this study.

\section{Availability of data and materials}

All data generated or analysed during this study are included in this published article.

\section{Declarations}

Ethics approval and consent to participate

The Ethical Committee for Medical Research of Faculty of Medicine, University of Indonesia, acknowledged this study.

\section{Consent for publication}

Not applicable

\section{Competing interests}

The authors declare that they have no competing interests.

\section{Author details}

'Department of Obstetrics and Gynecology, Cipto Mangunkusumo National Referral Hospital, Faculty of Medicine, University of Indonesia, Jakarta, Indonesia. ${ }^{2}$ Indonesian Reproductive Medicine Research and Training Center (INAREPROMED) Faculty of Medicine Universitas Indonesia, Dr. Cipto Mangunkusumo Hospital, Jakarta, Indonesia.

Received: 20 August 2021 Accepted: 6 December 2021

Published online: 29 January 2022

\section{References}

1. He W, Goodkind D, Kowal P. An aging world: 2015. Washington DC: U.S. Government Publishing Office; 2016.

2. Syakheeva D, Panasyuk M, Malganova I, Khairullin I. World population estimates and projections: data and methods. J Econ Econ Edu Res. 2016:17(2):1-11.

3. Clelan J, Agudelo A, Peterson H, Ross J, Tsui A. Contraception and health Lancet. 2012:380(1):149-56.

4. Darroch J, Singh S, for the Guttmacher Institute. Estimating unintended pregnancies averted from couple-years of protection (CYP). New York: Guttmacher Institute: 2011.

5. Guillebaud J. Contraception today. 7th ed. London: Informa Healthcare; 2012.

6. Statistics Indonesia and National Population and Family Planning Board Indonesia Demographic and Health Survey 2017. Ministry of Health: Jakarta; 2018

7. Sedgh G, Ashford LS, Hussain R. Unmet need for contraception in developing countries: examining women's reasons for not using a method. New York: Guttmacher Institute; 2016.

8. Bradley SEK, Croft TN, Fishel JD, Westoff CF. Revising Unmet Need for Family Planning. DHS Analytical Studies No 25. ICF International: Maryland; 2012.

9. World Health Organization. Rekomendasi Praktik Terpilih pada Penggunaan Kontrasepsi. Jenewa: WHO Press; 2016.
10. Schivone GB, Blumenthal PD. Contraception in the developing world: special considerations. Semin Reprod Med. 2016;34:168-74.

11. Gafar A, Suza DE, Efendi F, Has EM, Pramono AP, Susanto IA. Determinants of contraceptive use among married women in Indonesia. F1000 Res. 2020;9(193):1-9.

12. Mola PF, Suza DE, Efendy F, Setho H, Astutik E, Susanti IA. Factors associated with the use of contraception among women age 15-24 Years in Indonesia. Syst Rev Pharmacy. 2020;11(5):234-70.

13. Nurliawati $E$, Komariah E. Analysis of factors associated with the choice of contraception methods in fertile age couples at Kelurahan Kahuripan, Tasikmalaya City. Adv Health Sci Res. 2019;26:161-5.

14. Islam AZ, Mondal MN, Khatun ML, et al. Prevalence and determinants of contraceptive use among employed and unemployed women in Bangladesh. Int J MCH AIDS. 2016:5(2):92-102.

15. Adebowale SA, Adedini SA, Ibisomi LD, et al. Differential effect of wealth quintile on modern contraceptive use and fertility: evidence from Malawian women. BMC Women's Health. 2014;14(1):40.

16. Indrayawati N, Susiloretni KA, Najib N. The current use of contraception in Indonesia. J Kebidanan. 2019;9(2):174-7.

17. Bishwajit G, Tang S, Yaya S, Feng Z. Unmet need for contraception and its association with unintended pregnancy in Bangladesh. BMC Preg Childbirth. 2017;17(186):1-9.

18. Zulhijriani, Moedjiono Al, Mallongi A, Tamar M. Determinants of unmet need family planning in Indonesia (PMA 2015). Enfermeria Clinica. 2020;30(4):379-82

19. Dingeta T, Oljira L, Worku A, Berhane Y. Unmet need for contraception among young married women in eastern Ethiopia. Open Access J Contraception. 2019;10:89-101.

20. Gordon L. Birth control, history, and politics of. London: The Wiley Backwell Encyclopedia of Gender and Sexuality Studies; 2015.

\section{Publisher's Note}

Springer Nature remains neutral with regard to jurisdictional claims in published maps and institutional affiliations.

Ready to submit your research? Choose BMC and benefit from

- fast, convenient online submission

- thorough peer review by experienced researchers in your field

- rapid publication on acceptance

- support for research data, including large and complex data types

- gold Open Access which fosters wider collaboration and increased citations

- maximum visibility for your research: over $100 \mathrm{M}$ website views per year

At $\mathrm{BMC}$, research is always in progress.

Learn more biomedcentral.com/submissions 